University of Nebraska - Lincoln

DigitalCommons@University of Nebraska - Lincoln

1997

\title{
Genetic variation in North American leafy spurge (Euphorbia esula) determined by DNA markers
}

\author{
Martha L. Rowe \\ University of Nebraska-Lincoln \\ Donald J. Lee \\ University of Nebraska-Lincoln, dlee1@unl.edu \\ Scott Nissen \\ Colorado State University - Fort Collins, scott.nissen@colostate.edu \\ Brunella M. Bowditch \\ Trinity College \\ Robert A. Masters \\ University of Nebraska-Lincoln, rmasters1@unl.edu
}

Follow this and additional works at: https://digitalcommons.unl.edu/usdaarsfacpub

Part of the Agricultural Science Commons

Rowe, Martha L.; Lee, Donald J.; Nissen, Scott; Bowditch, Brunella M.; and Masters, Robert A., "Genetic variation in North American leafy spurge (Euphorbia esula) determined by DNA markers" (1997). Publications from USDA-ARS / UNL Faculty. 1085.

https://digitalcommons.unl.edu/usdaarsfacpub/1085

This Article is brought to you for free and open access by the U.S. Department of Agriculture: Agricultural Research Service, Lincoln, Nebraska at DigitalCommons@University of Nebraska - Lincoln. It has been accepted for inclusion in Publications from USDA-ARS / UNL Faculty by an authorized administrator of DigitalCommons@University of Nebraska - Lincoln. 


\section{Genetic variation in North American leafy spurge (Euphorbia esula) determined by DNA markers}

\author{
Martha L. Rowe \\ Corresponding author. Department of Agronomy, \\ University of Nebraska, Lincoln, NE 68583-0915
}

Donald J. Lee

Scott J. Nissen

Department of Agronomy, University of Nebraska, Lincoln, NE 68583-0915

Brunella M. Bowditch

Trinity College, Washington, DC 20017

Robert A. Masters

U.S. Department of Agriculture, Agricultural Research Service, University of Nebraska, Lincoln, NE 68583-0915

\begin{abstract}
Levels of inter- and intrapopulation genetic variation were determined in five North American populations of leafy spurge using chloroplast DNA (cpDNA) RFLPs and RAPD markers. Thirteen plastome types were identified among 123 individuals collected from five geographically separated populations. Number of plastomes within a population ranged from one to seven, with four of the populations having a predominate type plus one or more rarer types. Some plastome types were shared by populations, but plastome distribution among populations was nonrandom. RAPD markers indicated greatest relatedness among individuals within a population. Relatedness among populations as established through RAPDs was greater for geographically closer populations; this relationship was not observed for cpDNA markers. Differences in the range of movement for pollen and seed may account for differences between results of the cpDNA and RAPD analyses. The high degree of genetic variability among North American leafy spurge suggests possible multiple introductions or a high degree of variability within leafy spurge populations in its native range.
\end{abstract}

Nomenclature: Leafy spurge, Euphorbia esula L. EPHES.

Key words: Weed biocontrol, population genetics, genetic distance, chloroplast DNA, RFLPs, RAPDs, EPHES.
Leafy spurge is an introduced perennial rangeland weed with a remarkable capacity for both vegetative and sexual reproduction (Watson 1985). Aversion of cattle to grazing this plant and its displacement of desirable plants have made it a severe economic problem in the Great Plains of the U.S. and the prairie provinces of Canada. Leafy spurge has an extensive root system and ability to regenerate from both root and crown buds (Hanson and Rudd 1933; Messersmith et al. 1985). Chemical control methods that are effective are either environmentally undesirable or too expensive for use on rangeland. Many insect biocontrol agents collected from European leafy spurge have been released in North America. A number of these have found North American leafy spurge to be an unacceptable host (Harris 1991). Those insects that have shown success at some sites, such as species of the flea beetle Aphthona, have not been successful at all sites (N. E. Rees and R. Carlson, personal communication).

Factors that affect biocontrol agent establishment and ability to control a target plant include (1) synchrony in life cycles of host plant and agent, (2) adaptation of the agent to a new climate and habitat, (3) ability of the agent to find the host at varying densities, and (4) capacity of the agent to reproduce rapidly (Louda and Masters 1993). Genetic variability of the host plant may also play a role. A study of the relationship between biocontrol agent success and plant breeding system found that asexually reproducing plant species had a greater biocontrol success rate than plant species that reproduced sexually (Burdon and Marshall 1981). Although genetic variability was not determined for different plant species, it is likely that sexually reproducing species, especially outcrossing species, have greater genetic variability than do asexually reproducing species.

Biocontrol agents collected from populations near the center of origin of an introduced weed should be relatively good predators of that plant because of coevolutionary processes (Bartlett and Van den Bosch 1964). Anecdotal evidence suggests that North American leafy spurge was introduced to the northern Great Plains from southern Russia and Ukraine a little more than 100 years ago as a small grain contaminant (Dunn 1985), but actual number of Eurasian sources and introductions are unknown. If North American leafy spurge originated from one Eurasian source, then identification of this source would enhance efficiency of biocontrol agent collection. If North American leafy spurge derived from more than one Eurasian source and has been undergoing genetic mixing in this country, collections of biocontrol agents adapted to more genetically diverse leafy spurge would be warranted.

This study is a prelude to one in which North American and Eurasian leafy spurge will be compared in order to determine origins of the North American infestation. For the study on origins to be meaningful, it is necessary to have a measure of genetic variation in leafy spurge populations. Both chloroplast DNA (cpDNA) restriction fragment length polymorphism (RFLP) and random amplified polymorphic DNA (RAPD) analyses were used in the current study to assess intra- and interpopulation variation of North American leafy spurge.

Chloroplast DNA is a typically uniparentally (maternally in most angiosperms) inherited genome that does not undergo recombination and accumulates mutations slowly relative to the nuclear genome. These characteristics have made the chloroplast genome valuable for taxonomic studies where changes over time are assessed. The same characteristics make the leafy spurge chloroplast genome a potentially valuable tool for detecting regional differences in Eurasian leafy spurge, thereby making it possible to match North American leafy spurge with one or more source regions. A 
previous study (Nissen et al. 1992) demonstrated that variability in the leafy spurge chloroplast genome could be detected by hybridization-based RFLP analysis using mung bean (Vigna radiata (L.) Wilezek var. radiata) cpDNA fragments as hybridization probes. This type of analysis detects both nucleotide substitutions and rearrangements in cpDNA, does not require labor-intensive isolation of cpDNA, and utilizes existing cpDNA probe libraries. RAPD analysis detects primarily changes in the nuclear genome because there are a large number of unique nucleotide sequences available for primer binding in the nuclear genome relative to organellar genomes. RAPD analysis was used to confirm individuality of plant samples and to detect differences among populations that would not be apparent from study of maternal lineages alone.

\section{Materials and Methods}

\section{Tissue Collection}

Leafy spurge tissue was collected from five sites in North America: Larimer Co., CO; Richland Co., ND; Minnehaha Co., SD; Brown Co., NE; and Lancaster Co., NE. Young leaf tissue from 23 to 30 individuals per site was collected and freeze-dried. An effort was made to sample from widely spaced crowns to minimize collection of genetically identical plants resulting from vegetative propagation. In some cases, where young leaf material was scanty on stems from a single crown, tissue from stems within $1 \mathrm{~m}$ of each other was sampled. Where possible, however, tissue was collected from single crowns.

Leaf tissue was also collected from single North American (Nebraska, Montana) and Eurasian (Austria, Hungary, Italy, Russia, Turkey, Yugoslavia) ${ }^{1}$ plants for preliminary studies to select appropriate restriction enzymes. A single individual of sun spurge (Euphorbia helioscopia L.), an annual euphorb collected in Italy and growing in the Weed Science greenhouse, was included in the cpDNA RFLP analysis as a distinct species against which to assess variation found in leafy spurge chloroplast DNA.

\section{DNA Extraction}

Total genomic DNA was extracted from samples (200 to $400 \mathrm{mg}$ ) of dried material by the method of Saghai-Maroof et al. (1984), using a cetyltrimethylammonium bromide (CTAB) buffer and chloroform/octanol extractions. DNA concentrations were determined by fluorometer using DNAspecific dye Hoechst 33258. ${ }^{2}$

\section{Chloroplast DNA RFLP Analysis}

Leafy spurge DNA was digested with restriction enzymes (see restriction enzyme/probe survey) and DNA fragments separated by agarose gel electrophoresis. From each restriction enzyme digest, five $\mu \mathrm{g}$ digested total DNA were loaded per lane on a gel of either $0.8 \%$ agarose $^{3}$ or $0.5 \%$ agarose/ $0.25 \%$ Synergel, ${ }^{4}$ and electrophoresed for $23 \mathrm{~h}$ at 25 volts. Separated DNA fragments were transferred onto Hybond $\mathrm{N}^{5}$ nylon membranes by neutral Southern transfer. DNA was fixed firmly to the nylon membrane by UV-crosslinking at $130,000 \mathrm{~mJ}$ in a Stratalinker $2400,{ }^{6}$ then baked at $60 \mathrm{C}$ overnight.
Because the total DNA digests included fragments of mitochondrial and nuclear DNA as well as cpDNA, fourteen mung bean cpDNA restriction fragments were used as hybridization probes to identify leafy spurge cpDNA. Preliminary work (Nissen et al. 1992) showed that mung bean cpDNA fragments representing a large proportion of the chloroplast genome had enough homology with leafy spurge cpDNA to hybridize to membrane-bound leafy spurge DNA fragments and detect polymorphisms among individual leafy spurge cpDNAs.

The fourteen mung bean cpDNA PstI and SalI restriction fragments (Palmer et al. 1988; Palmer and Thompson 1981 ) were cloned into the plasmid vector pBR322 and reproduced in transformed $E$. coli. Plasmids containing cpDNA inserts were isolated by mini-preps (Birnboim and Doly 1979) (MagicMinipreps ${ }^{7}$ ). Inserts separated from the vector by digestion with $\mathrm{PstI}_{\mathrm{I}}$ or $\mathrm{Sall}^{7}$ were isolated on lowmelting-point agarose ${ }^{3}$ gels. Bands containing the inserts were cut from the gels and incubated with $10 \mathrm{mM}$ Tris, 1 mM EDTA buffer ( $\mathrm{pH} 8$ ) at $68 \mathrm{C}$ for $10 \mathrm{~min}$, followed by freezing to release the inserts. Isolated inserts were labelled with digoxigenin-11-2'-deoxyuridine-5'-triphosphate (dig$\mathrm{dUTP})^{8}$ by random priming (Feinberg and Vogelstein 1983).

Labelled mung bean cpDNA inserts were used as hybridization probes by allowing them to incubate overnight at 68 $\mathrm{C}$ with prehybridized Southern blot membranes containing leafy spurge restriction fragments. Stringency washes of membranes, to remove weakly bound mung bean probe fragments, were conducted twice at room temperature for 5 min each using $2 \mathrm{X}$ SSC buffer $(0.3 \mathrm{M} \mathrm{NaCl}, 0.3 \mathrm{M}$ sodium citrate) with $0.1 \%$ SDS, and twice at $68 \mathrm{C}$ for 15 min each using $0.1 \mathrm{X}$ SSC buffer $\left(1.5\right.$ by $10^{-2} \mathrm{M} \mathrm{NaCl}, 1.5$ by $10^{-4}$ $M$ sodium citrate) with $0.1 \%$ SDS. Digoxigenin-labelled mung bean cpDNA probe fragments that hybridized to leafy spurge fragments on the Southern blot were treated with anti-digoxigenin antibody conjugated to alkaline phosphatase. ${ }^{8}$ Location of probes, and therefore leafy spurge cpDNA fragments, was visualized on Southern blots using a chemiluminescent substrate ${ }^{8}$ for the alkaline phosphatase, and varying exposures to $\mathrm{XAR} 5^{9} \mathrm{X}$-ray film.

\section{Restriction Enzyme/Probe Survey}

An initial survey with eleven restriction enzymes (BamHI, BclI, CfoI, ClaI, EcoRI, EcoRV, HindIII, HpaII, $\left.K p n I, X b a I, X h o I^{7}\right)$ and individual leafy spurge accessions was conducted to determine which restriction enzymes would reveal the largest differences in cpDNA. DNA from Nebraska, Montana, Austria, Italy, and Russia leafy spurge plants was digested with EcoRI (Nissen et al. 1992), and DNA of individuals from Nebraska, Montana, Austria, Turkey, Hungary, Yugoslavia, and Russia was digested with the other 10 enzymes. Enzymes revealing most polymorphisms among accessions using the $14 \mathrm{cpDNA}$ probes were EcoRI, $E c o$ RV, and Hind III. These restriction enzymes were used in the subsequent examination of cpDNA variation within and among North American populations of leafy spurge. The restriction enzyme/probe combinations selected as potentially most informative were as follows: EcoRI/probes 5, 7 or $8,9,11 ; E c o R V /$ probes 2, 4a, 4b, 5, 6, 7, 9, 11, 13; and Hind III/probes 1, 2, 3, 4a, 4b, 5, 6, 7, 9, 10, 11, 12, 13. 


\section{RAPD Analysis}

Six 9-base primers that gave consistent amplified DNA products during an initial screening were used in RAPD analysis of the North American leafy spurge populations. DNA was amplified according to established RAPD protocols (Williams et al. 1990). Each RAPD reaction occurred in $25 \mu$ l, containing $10 \mathrm{mM}$ Tris- $\mathrm{HCl}(\mathrm{pH} \mathrm{9.0);50} \mathrm{mM}$ $\mathrm{KCl} ; 1.5 \mathrm{mM} \mathrm{MgCl} 2 ; 0.1 \mathrm{mM}$ each of dATP, dCTP, dTTP, and dGTP; 6 pmol of a single primer; 20 ng of DNA template; and 1 to 1.2 units of Taq polymerase. ${ }^{7}$ Reactions were performed in a Perkin-Elmer Cetus DNA Thermalcycler ${ }^{10}$ programmed for 45 cycles of $1 \mathrm{~min}$ at $94 \mathrm{C}, 1 \mathrm{~min}$ at 35 $\mathrm{C}$, and $2 \mathrm{~min}$ at $72 \mathrm{C}$. Minimum ramping times between incubation cycles were used, and reactions were held at $4 \mathrm{C}$ until analyzed.

Amplification products were separated by electrophoresis on a $1.4 \%$ agarose gel stained with ethidium bromide. Gels were run in IX TBE $(89 \mathrm{mM}$ Tris base, $89 \mathrm{mM}$ boric acid, $2 \mathrm{mM}$ EDTA, pH 8.3) for approximately $3 \mathrm{~h}$ and photographed under transmitted UV light (Bowditch et al. 1993; Williams et al. 1990). All reactions were repeated three times to test for reproducibility.

All bands detected for each population were given approximate molecular weights based on their positions relative to markers of known molecular weights on the agarose gels and scored as presence or absence of the band. Any bands that showed variation within repeated amplifications of individual DNA samples were not scored.

\section{Statistical Procedures}

Statistical procedures that assessed frequency and similarity of genotypes were utilized to compare intra- and interpopulation variation. Nucleon diversity measures variation among plastome types within a population as a function of the probability that two randomly chosen genomes from a population are different (Nei 1987; Equations 8.4 and 8.12 modified for a haploid genome as in Milligan 1991).

$$
\begin{aligned}
\hat{b} & =n \frac{\left(1-\sum \hat{x}_{i}^{2}\right)}{(n-1)} \\
\mathrm{V}(\hat{b}) & =\frac{2}{n(n-1)}\left\{2(n-2)\left[\sum \hat{x}_{i}^{3}-\left(\sum \hat{x}_{i}^{2}\right)^{2}\right]+\sum \hat{x}_{i}^{2}-\left(\sum \hat{x}_{i}^{2}\right)^{2}\right\}
\end{aligned}
$$

The entire chloroplast genome was treated as a unit for which frequencies could be calculated, without considering which molecular events caused differences among plastome types. In Equations 1 and 2, $\hat{x}_{i}$ was the sample frequency of the $i$ th plastome type and $n$ was the sample size. Nucleon diversity values were affected by both the number of different genotypes and the frequency of each type. The greater the number of genotypes and the more evenly distributed the individuals among those genotypes, the higher the nucleon diversity.

Extent of nonrandom distribution of plastome types in the five populations was measured by the $\mathrm{G}_{\mathrm{ST}}$ equation of Nei (Nei 1987, Equation 8.27),

$$
\mathrm{G}_{\mathrm{ST}}=\mathrm{D}_{\mathrm{ST}} / \mathrm{H}_{\mathrm{T}}
$$

which determined proportion of total chloroplast genetic diversity due to differences among populations. $\mathrm{D}_{\mathrm{ST}}$, a measure of diversity among subpopulations, was the difference in $\mathrm{H}_{\mathrm{T}}$, the total genetic diversity of a subdivided population, and $\mathrm{H}_{S}$, diversity within the subpopulations (Nei 1987, Equations 8.31 and 8.32 , respectively).

$$
\begin{gathered}
\hat{H}_{S}=\frac{2 n\left(1-\overline{\sum \hat{x}_{i}^{2}}\right)}{(2 n-1)} \\
\hat{H}_{T}=\frac{1-\sum \bar{x}_{i}^{2}+\hat{H}_{S}}{(2 n s)}
\end{gathered}
$$

In estimates of $\mathrm{H}_{\mathrm{S}}$ and $\mathrm{H}_{\mathrm{T}}, n$ was the sample size, $\hat{x}_{i}$ was the frequency of the $i$ th plastome type, and $s$ was the number of subpopulations. $1-\bar{\Sigma} \hat{x}_{i}^{2}$ was a measure of the amount of within-subpopulation plastome diversity averaged over the subpopulations; the more plastome types in a subpopulation, the lower the frequency of each, the lower the quantity $\overline{\Sigma \hat{x}_{i}^{2}}$, and the higher the plastome diversity. $1-\Sigma \bar{x}_{i}^{2}$ was the plastome diversity over the entire population; the average squared frequency of each plastome across subpopulations was small if there were many plastome types, therefore making $\Sigma x_{i}^{2}$ small and the overall population diversity large. In our application of this statistic, the chloroplast genome was considered a single locus with many allelic forms.

A resampling scheme (Stoneking et al. 1990) was used to generate test populations to determine if the distribution of plastome types was due to chance. All individuals sampled were randomly assigned to five populations and an overall $\mathrm{G}_{\mathrm{ST}}$ was calculated for each resampled population. This random resampling was repeated 1,000 times.

Nucleon diversity and $\mathrm{G}_{S T}$ allowed comparison of populations based on plastome type and frequency. They did not take into account degree of similarity and possible relatedness among different plastome types. Genetic similarity (GS) (Dice 1945; Nei and Li 1979) was used to measure the proportion of fragments shared by two plastome types.

$$
\mathrm{GS}=2 m_{X Y} /\left(m_{X}+m_{Y}\right)
$$

In this equation $m_{X Y}$ was the number of restriction fragments shared by two genotypes, $X$ and $Y$, and $m_{X}$ and $m_{Y}$ were the total number of fragments for each genotype. In the current work, fragment data rather than restriction site data were used for determination of GS because the genetic basis for each polymorphism has not yet been determined. A future conversion of the data to reflect genetic events rather than simple presence or absence of fragments may alter the GS values somewhat.

An average $G S$ was also calculated within $\left(G S_{\mathrm{A}(\mathrm{W})}\right)$ and between $\left(\mathrm{GS} \mathrm{S}_{\mathrm{A}(\mathrm{B})}\right)$ populations. For $\mathrm{GS} \mathrm{A}_{\mathrm{A}(\mathrm{W})}$, each individual was compared to every other individual within its own population. GS values for each comparison were summed, then divided by the total number of comparisons. $\mathrm{GS}_{\mathrm{A}(\mathrm{B})}$ was calculated by comparing each individual in a first population to every other individual in a second population. GS values for each comparison were summed and divided by the total number of comparisons. $\mathrm{GS}_{\mathrm{A}(\mathrm{B})}$ was determined for every pairwise combination of populations.

A cluster diagram was constructed based on the un- 


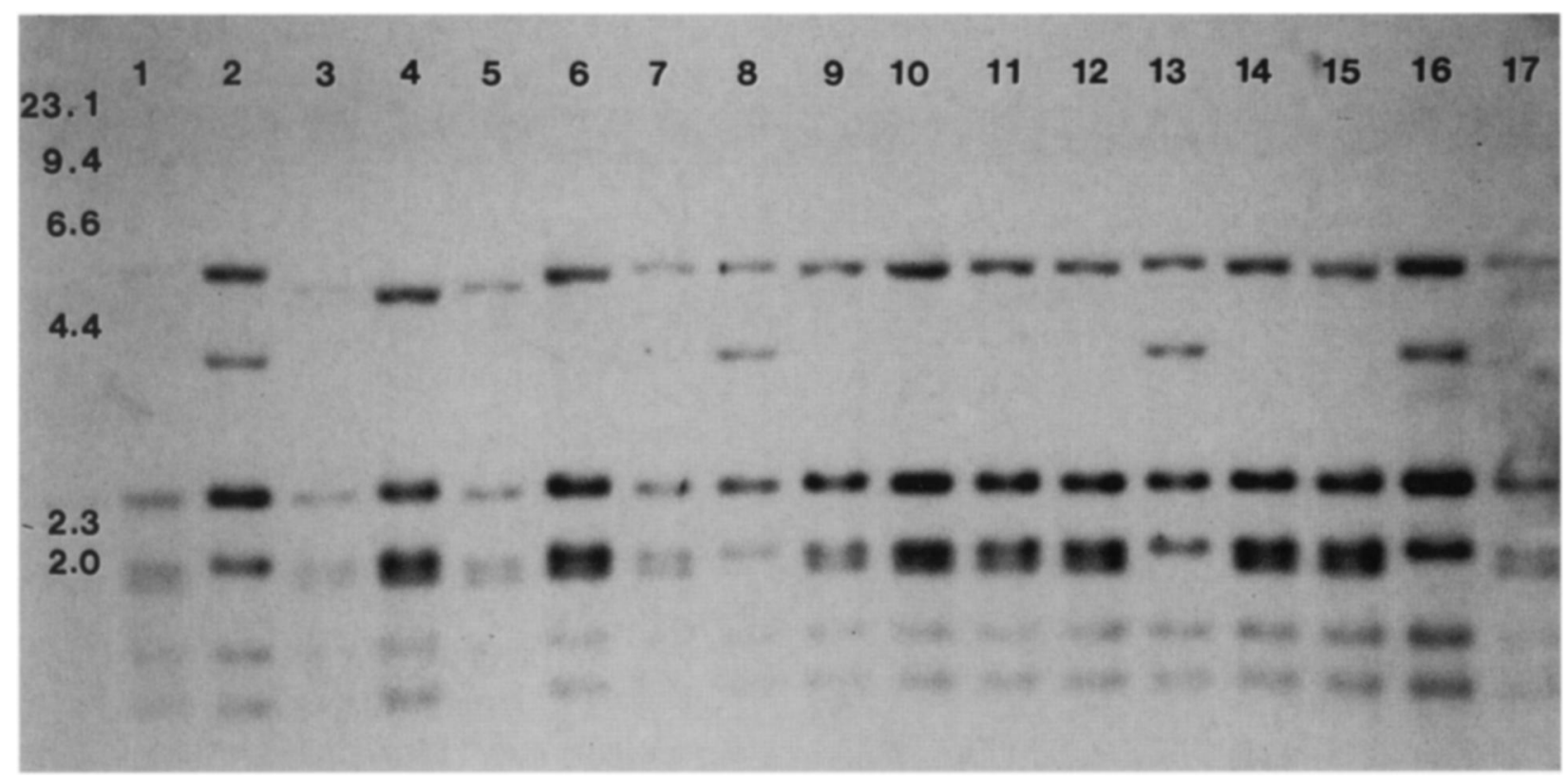

FIGURE 1. Representative restriction fragment patterns for leafy spurge individuals from five North American populations. Leafy spurge total DNA was digested with EcoRI and subjected to agarose gel electrophoresis. Southern blot was probed with mung bean chloroplast DNA clone 11 (20). Polymorphisms shown have not been completely mapped, but may be the result of two restriction site mutations: a 5.1-kb fragment (Lanes $1,2,6-17)$ replaced by a 4.9-kb fragment (lanes 3-5) plus a 0.2-kb fragment that was too small to be detected on this gel, and a 3.6-kb fragment (Lanes 2, 8, 13, 16) replaced by two 1.8-kb fragments (Lanes 1, 3-7, 9-12, 14, 15, 17) (4). Leafy spurge populations represented: Lanes 1-2, Colorado, Larimer Co.; Lanes 3-5, North Dakota, Richland Co.; Lanes 6-8, South Dakota, Minnehaha Co.; Lanes 9-12, Nebraska, Lancaster Co.; Lanes 13-19, Nebraska, Brown Co.

weighted pair-group method using arithmetic average (UPGMA). Genetic distance and cluster analyses were calculated using a PC-SAS program provided by Steve Wall, Pioneer Hi-Bred International, Inc., Johnston, IA. These were based on genetic dissimilarity values $(1-G S)$ among the genotypes detected with cpDNA and RAPD data. Dendrograms generated by the cluster analysis program provided visual representation of genetic dissimilarities and grouping of genotypes based on fragment patterns.

\section{Results and Discussion}

\section{CpDNA Polymorphisms}

Heterologous probes detected leafy spurge cpDNA polymorphisms throughout the chloroplast genome, which has been estimated at 120,000 to 150,000 base pairs in leafy spurge (Nissen et al. 1992). Digested DNAs from representatives of each population were run on a common gel so

TABLE 1. Leafy spurge chloroplast DNA polymorphisms.

\begin{tabular}{|c|c|c|}
\hline Enzyme/probe & $\begin{array}{c}\text { Polymorphic } \\
\text { fragments }(k b)\end{array}$ & $\begin{array}{l}\text { Chloroplast genome } \\
\text { location }\end{array}$ \\
\hline EcoRI/7,8 & $17.2,14.6,2.6$ & Large single copy region \\
\hline EcoRI/9 & $\begin{array}{l}2.4,1.9,1.9,{ }^{\mathrm{a}} 1.8 \\
\quad 1.7\end{array}$ & Large single copy region \\
\hline EcoRI/10,11,12 & $5.1,4.9,3.6,1.8$ & Large single copy region \\
\hline HindIII/1,2,4a & $9.6,5.5,4.1$ & Inverted repeat \\
\hline HindIII/3 & $6.3,4.5,1.8$ & Small single copy region \\
\hline HindIII/7 & $6.4,6.0$ & Large single copy region \\
\hline EcoRV/5 & $6.7,2.3,2.2$ & Large single copy region \\
\hline EcoRV/7 & $2.7,2.3$ & Large single copy region \\
\hline EcoRV/9 & $2.5,2.4,2.2$ & Large single copy region \\
\hline
\end{tabular}

a Same size, but different 1.9-kb fragment. polymorphisms could be directly compared (Figure 1). All 14 mung bean fragments were used to probe the common blots.

Complete information was obtained for 123 North American individuals. Fragments with identical molecular weights detected by adjacent probes were identified and counted only once. Three fragments detected by Eco$\mathrm{RI} /$ probe 9 and three fragments detected by HindIII/probes $4 \mathrm{~b}$ and 5 were polymorphic but difficult to identify accurately on some blots because of small molecular weight differences. Fragments that could not be scored reliably in each of these enzyme/probe combinations were combined into single molecular weight categories. Because of this pooling, the data presented in this paper represent a conservative estimate of genetic variation among North American leafy spurge.

A total of $80 \mathrm{cpDNA}$ fragments were detected. Nine probe/enzyme combinations revealed polymorphisms, which provided a nonrepetitious means of differentiating leafy spurge genotypes (Table 1). Three of the polymorphisms were obvious restriction site changes based on the observation that one higher molecular weight fragment present in some individuals was replaced in others by two smaller fragments, the additive molecular weights of which equaled that of the larger fragment (Brumbaugh 1993). Two fragments generated by "gain" of any restriction site were counted as one fragment. Mapping studies are underway to determine the nature of the remaining polymorphisms.

North American leafy spurge appeared to have a high degree of cpDNA variation. Even with a small number of restriction enzymes and conservative scoring, 13 different plastome types were detected among the 123 North American individuals included in this study (Table 2). One of the five populations (ND) had a single plastome type. Three 
TABle 2. Plastome type frequency in five North American leafy spurge populations.

\begin{tabular}{|c|c|c|c|c|c|c|c|}
\hline \multirow{2}{*}{$\begin{array}{l}\text { cpDNA } \\
\text { geno- } \\
\text { type }\end{array}$} & \multicolumn{5}{|c|}{ Population $^{\mathrm{a}}$} & \multirow{2}{*}{$\begin{array}{l}\text { Total } \\
\text { no. } \\
\text { each } \\
\text { type }\end{array}$} & \multirow{2}{*}{$\begin{array}{l}\text { Genotype } \\
\text { frequency }\end{array}$} \\
\hline & $\mathrm{CO}$ & ND & SD & NE-B & NE-L & & \\
\hline 1 & 22 & 23 & & 1 & & 46 & 0.37 \\
\hline 2 & & & & 7 & 19 & 26 & 0.21 \\
\hline 3 & & & 17 & 6 & 2 & 25 & 0.20 \\
\hline 4 & & & & 6 & & 6 & 0.05 \\
\hline 5 & & & 1 & & 4 & 5 & 0.04 \\
\hline 6 & & & 2 & 2 & & 4 & 0.03 \\
\hline 7 & 3 & & & & & 3 & 0.02 \\
\hline 8 & & & 2 & & 1 & 3 & 0.02 \\
\hline 9 & & & 1 & & & 1 & 0.01 \\
\hline 10 & & & 1 & & & 1 & 0.01 \\
\hline 11 & 1 & & & & & 1 & 0.01 \\
\hline 12 & & & & & 1 & 1 & 0.01 \\
\hline 13 & & & & 1 & & 1 & 0.01 \\
\hline Total & 26 & 23 & 24 & 23 & 27 & 123 & 1.00 \\
\hline
\end{tabular}

${ }^{a} \mathrm{CO}=$ Colorado, Larimer Co.; ND = North Dakota, Richland Co.; $\mathrm{SD}=$ South Dakota, Minnehaha Co.; NE-B = Nebraska, Brown Co.; NE-L $=$ Nebraska, Lancaster Co.

populations (CO, SD, and NE-L) contained predominant plastome types representing more than $70 \%$ of individuals in that sample. Each sample had a different predominant type, although the predominant type in population $\mathrm{CO}$ was identical to the single plastome type in population ND. One sample (NE-B) did not have a single major type but rather, several low frequency plastome types. The major type from population NE-L was also the highest frequency type in population NE-B, although this genotype represented only $30 \%$ of the plastome types in this latter sample.

This study illustrated that intraspecific and intrapopulation cpDNA variation may be present even in introduced species. Early studies of cpDNA downplayed intraspecific variation, often because the goal was to distinguish species or families and because intraspecific sampling was minimal; however, more extensive sampling has revealed a considerable amount of variability in cpDNA within species (Harris and Ingram 1991; Soltis et al. 1992). The level of cpDNA variation observed in this study was comparable to that documented in other investigations where many individuals within a species were sampled (Milligan 1991; Neale et al. 1986).

Total chloroplast diversity, as measured by nucleon diversity (Table 3 ) in the combined North American sample, was similar to that for wild barley (Hordeum vulgare L. ssp. spontaneum) (Milligan 1991, from data in Neale et al. 1986) and red clover (Trifolium pratense L.) (Milligan 1991). However, nucleon diversity varied widely among the five North American leafy spurge populations (Table 3). For population ND, nucleon diversity was zero since that sample contained only one plastome type. Population CO also had low nucleon diversity because there were only two rare types and one predominant type. Samples from populations SD and NE-L had intermediate nucleon diversities. The largest nucleon diversity was found in population NE-B with seven different plastome types, none of which were present at a high frequency. Milligan (1991), in a study of cpDNA variation in three populations of red clover, found that each had the same major plastome type and numerous rarer
Table 3. Nucleon diversity for plastomes within North American leafy spurge populations and in the combined sample.

\begin{tabular}{lccc}
\hline Population $^{\mathrm{a}}$ & $\begin{array}{c}\text { No. of } \\
\text { individuals }\end{array}$ & $\begin{array}{c}\text { Nucleon } \\
\text { diversity }\end{array}$ & Variance $^{\mathrm{b}}$ \\
\hline CO & 26 & 0.289 & 0.042 \\
ND & 23 & 0.000 & 0.000 \\
SD & 24 & 0.500 & 0.056 \\
NE-B & 23 & 0.814 & 0.031 \\
NE-L & 27 & 0.493 & 0.048 \\
Combined sample & 123 & 0.780 & 0.006 \\
\hline
\end{tabular}

${ }^{a} \mathrm{CO}=$ Colorado, Larimer Co.; ND = North Dakota, Richland Co. $\mathrm{SD}=$ South Dakota, Minnehaha Co.; NE-B = Nebraska, Brown Co.; NE-L = Nebraska, Lancaster Co.

${ }^{\mathrm{b}}$ Estimates of nucleon diversity and its variance were determined using equations $\left[\hat{b}=n\left(1-\Sigma \hat{x}_{i}^{2}\right) /(n-1)\right]$ and $[\mathrm{V}(\hat{b})=2 /(n(n-1))\{2(n-2)$ $\left.\left.\left[\Sigma \hat{x}_{i}^{3}-\left(\Sigma \hat{x}_{i}^{2}\right)^{2}\right]+\Sigma \hat{x}_{i}^{2}-\left(\Sigma \hat{x}_{i}^{2}\right)^{2}\right\}\right]$, respectively. As in Milligan (1991), the equations were modified for a sample size of $n$ haplotypes rather than a sample size of $2 n$ alleles.

types, some of which were unique to a population. Nucleon diversities for individual red clover populations were not very different from the overall sample nucleon diversity, suggesting similar population structures even though there were many rare plastome types unique to single populations. $\mathrm{Al}$ though three of five North American leafy spurge populations had predominant plastome types and some unique rare types, predominant types were not the same in each population, and two leafy spurge populations had structures very different from the red clover populations, one with a single plastome type and the other with numerous low frequency types but no predominant type. Observed patterns of plastome distribution could be due to different origins of individuals in a population, age of a population, or microhabitat.

Extent of nonrandom distribution of plastome types in the five leafy spurge populations was measured with the $\mathrm{G}_{\mathrm{ST}}$ statistic. Randomly dividing the 123 individuals into five groups 1,000 times failed to generate a single $\mathrm{G}_{\mathrm{ST}}$ value as large as that observed among the five population samples. Thus, it was concluded that distribution of plastome types in the North American populations was nonrandom. The overall $\mathrm{G}_{\mathrm{ST}}$ value for the combined North American sample (Table 4) indicated that roughly $46 \%$ of total cpDNA diversity was due to differences among populations, while the remaining $54 \%$ of total diversity was due to variation within populations. By contrast, in the red clover study (Milligan 1991), less than $5 \%$ of the total cpDNA diversity was due to differences among populations. When leafy spurge populations were analyzed in a pairwise manner, the proportion of total chloroplast genetic diversity due to differences between populations ranged from 0.06 to 0.61 (Table 4). $\mathrm{G}_{\mathrm{ST}}$ values for population pairs $\mathrm{CO} / \mathrm{ND}, \mathrm{SD} / \mathrm{NE}-\mathrm{B}$, and NE-B/NE-L were very small, indicating that within-population variation was much greater than between-population variation. Comparisons ND/SD and ND/NE-L had larger $\mathrm{G}_{S T}$ values because no plastome types were shared in these pairings.

Evaluations of plastome type frequencies did not offer information on similarities of types. GS values were used to calculate the apparent relatedness among plastome types within a given population and among populations. The three predominant North American plastome types (Types 1,2 , and 3; Table 2), comprising $78 \%$ of the plastomes 
TABLE 4. Comparison of chloroplast genome diversity among five populations of leafy spurge and between population pairs.

\begin{tabular}{lccc}
\hline Population pair & $\mathrm{H}_{\mathrm{S}}$ & $\mathrm{H}_{\mathrm{T}}$ & $\mathrm{G}_{\mathrm{ST}}$ \\
\hline CO/ND & 0.140 & 0.154 & 0.088 \\
CO/SD & 0.390 & 0.686 & 0.432 \\
CO/NE-B & 0.546 & 0.733 & 0.254 \\
CO/NE-L & 0.387 & 0.691 & 0.441 \\
ND/SD & 0.250 & 0.627 & 0.601 \\
ND/NE-B & 0.407 & 0.677 & 0.399 \\
ND/NE-L & 0.247 & 0.638 & 0.612 \\
SD/NE-B & 0.657 & 0.738 & 0.109 \\
SD/NE-L & 0.496 & 0.712 & 0.302 \\
NE-B/NE-L & 0.653 & 0.692 & 0.057 \\
Combined sample & 0.417 & 0.772 & 0.460 \\
\hline
\end{tabular}

a Within-population diversity $\left(\mathrm{H}_{\mathrm{S}}\right)$ and total diversity $\left(\mathrm{H}_{\mathrm{T}}\right)$ were calculated from equations $\left[\hat{H}_{\mathrm{S}}=2 n\left(1-\overline{\Sigma \hat{x}_{i}^{2}}\right) /(2 n-1)\right]$ and $\left[\hat{H}_{\mathrm{T}}=1-\right.$ $\left.\Sigma x_{i}^{2}+\hat{H}_{S} /(2 n s)\right]$, respectively. Among-population diversity $\left(\mathrm{D}_{\mathrm{ST}}\right)$ was calculated from $\mathrm{H}_{\mathrm{T}}-\mathrm{H}_{\mathrm{S}}$, and $\mathrm{G}_{\mathrm{ST}}$ from equation $\left[\mathrm{G}_{\mathrm{ST}}=\mathrm{D}_{\mathrm{ST}} / \mathrm{H}_{\mathrm{T}}\right]$.

${ }^{\mathrm{b}} \mathrm{CO}=$ Colorado, Larimer Co.; ND = North Dakota, Richland Co.; $\mathrm{SD}=$ South Dakota, Minnehaha Co.; NE-B = Nebraska, Brown Co.; NE-L = Nebraska, Lancaster Co.

sampled, showed genetic similarities ranging from 0.59 to 0.94 (Table 5). This range of GS values was representative of all North American plastome types sampled. Genetic similarity between Plastome Type 1 , the predominant type found in populations $\mathrm{CO}$ and $\mathrm{ND}$, and either Plastome Type 2 (predominant in SD) or Type 3 (predominant in $\mathrm{NE}-\mathrm{L}$ and most frequent type in NE-B) was much lower than the GS value between Types 2 and 3. For comparison, the genetic similarity of sun spurge and North American leafy spurge plastomes was calculated. Values ranged from 0.27 to 0.32 , indicating a more distant relationship with leafy spurge.

Average GS values (Table 6) within and between populations took into account both similarity and frequency of plastomes. Average GS also supported greater similarity of populations $\mathrm{CO}$ and ND to each other than either compared with the other three populations. Higher $\mathrm{GS}_{\mathrm{A}(\mathrm{B})}$ values for populations $\mathrm{CO}$ and ND were due to the large number of individuals sharing a plastome type in the two populations. Populations SD, NE-B, and NE-L were not as similar to each other as were $\mathrm{CO}$ and $\mathrm{ND}$, but showed greater similarity to each other than to either CO or ND. Population $\mathrm{CO}$ had an average within population GS (0.900) that was comparable to the $\mathrm{GS}_{\mathrm{A}(\mathrm{W})}$ of $\mathrm{SD}, \mathrm{NE}-\mathrm{B}$, and NE-L $(0.894,0.860,0.911$, respectively). In contrast, nucleon diversity of $\mathrm{CO}$ was considerably lower than nucleon diversity of SD, NE-B, or NE-L (Table 3). The average GS statistic quantified the similarity of plastome types between and within populations while nucleon diversity did not.

A dendrogram based on genetic dissimilarities (Figure 2) illustrated the cpDNA diversity found within some populations. As in the GS analysis (Table 5), cluster analysis showed that the predominant type shared by populations $\mathrm{CO}$ and ND (Type N01 in Figure 2) was distinct from the other two predominant types (N02 and N03 in Figure 2), which clustered relatively near to each other. Both GS values and cluster analysis also indicated that plastomes within a single population were not necessarily most similar to each other. It is not likely that rare types within a population represented the same lineage as the predominant type. Divergent $\mathrm{cPDNA}$ genotypes within a population may be the
TABLE 5. Genetic similarity among North American leafy spurge plastome types and between leafy spurge and an out-type Euphorbia species.

\begin{tabular}{lccc}
\hline Plastome type $^{\mathrm{a}}$ & 1 & 2 & 3 \\
\hline 2 & 0.588 & & \\
3 & 0.647 & 0.941 & \\
E. helioscopia & 0.324 & 0.270 & 0.324 \\
\hline
\end{tabular}

a Type 1 = predominant plastome type in Populations CO and ND. Type 2 = predominant plastome type in Population NE-B; also found in NE-L. Type 3 = predominant plastome type in Population SD.

result of either mixing of individuals from different Eurasian origins, each with a different maternal ancestry, or introduction of individuals from Eurasian populations already comprised of a mixture of maternal types.

\section{RAPD Analysis}

The number of bands scored for each nine-base primer ranged from five to 25 . Three bands were fixed in all populations; two bands were unique to $\mathrm{CO}$ and one to NE-L. All other bands were shared by two or more populations. Analysis of leafy spurge population structure and relatedness based on cpDNA suggested that diverse maternal lineages make up North American populations. Two questions arose from the cpDNA study: (1) Were single individuals being sampled? When a single plastome type was found, as in the North Dakota population, was this due to repeat sampling of a few individuals with the same plastome type that had spread out over time as large clones, or were individual samples truly separate plants with the same plastome type? Leafy spurge has been present longer in North Dakota than in the other states involved in this study, and it was possible that ND was an older population consisting of large, clonal individuals. (2) Would analysis of differences in the nuclear genome be congruent with the population structure and relatedness measured by cpDNA? Leafy spurge, an outcrossing species, would undergo genetic mixing and recombination in its nuclear genome while the chloroplast genome would not, presuming maternal inheritance. RAPDs, which predominantly sampled the nuclear genome, were used to assess relatedness of nuclear genomes within and among populations.

CpDNA RFLP data identified 13 plastome types among the 123 leafy spurge individuals, but each individual analyzed by RAPDs had a unique genotype. Unique nuclear genomes of individuals was true even for population ND, which exhibited only one plastome type, indicating that sexually produced individuals were collected.

TABLE 6. Average plastome GS, expressing genetic similarity within and between North American leafy spurge populations.

\begin{tabular}{lccccc}
\hline $\begin{array}{l}\text { Popula- } \\
\text { tion }^{2}\end{array}$ & CO & ND & SD & NE-B & NE-L \\
\hline CO & 0.900 & & & & \\
ND & 0.944 & 1.000 & & & \\
SD & 0.686 & 0.650 & 0.894 & & \\
NE-B & 0.709 & 0.683 & 0.868 & 0.860 & \\
NE-L & 0.650 & 0.606 & 0.869 & 0.872 & 0.911 \\
\hline
\end{tabular}

${ }^{a} \mathrm{CO}=$ Colorado, Larimer Co.; ND = North Dakota, Richland Co.; $\mathrm{SD}=$ South Dakota, Minnehaha Co.; NE-B = Nebraska, Brown Co.; NE-L $=$ Nebraska, Lancaster Co. 


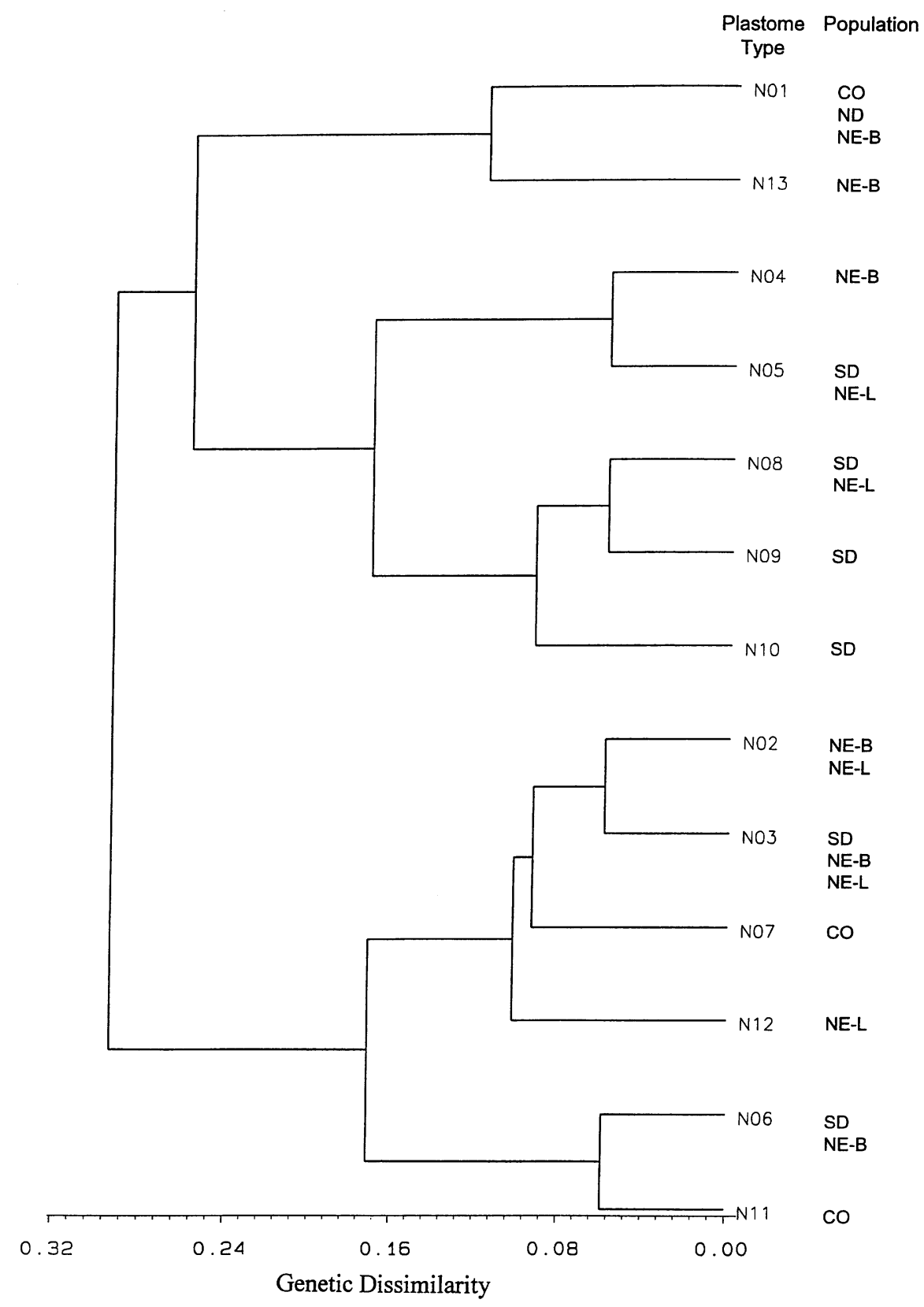

FIGURE 2. Dendrogram showing relationships of 14 chloroplast DNA genotypes detected in five North American leafy spurge populations. N01 through N14 represent 14 plastome types detected. Populations represented: CO = Colorado, Larimer Co.; ND = North Dakota, Richland Co.; SD = South Dakota, Minnehaha Co.; NE-B = Nebraska, Brown Co.; NE-L = Nebraska, Larimer Co.

Cluster analysis (Figure 3) showed that, with a few exceptions, individuals within a population had greatest similarity to one another. The greatest population dissimilarity as measured by RAPDs was between the $\mathrm{CO}$ population and the populations in ND, SD, and NE. This was in contrast to the cpDNA RFLP data, which suggested a greater similarity between populations $\mathrm{CO}$ and ND. It is interesting that these two populations, which were farthest apart geographically, were the most alike based on plastome types, but very divergent based on RAPDs. RAPDs (Figure 3 ) and cpDNA RFLP data (Table 6; Figure 2) were in closer agreement for populations NE-B, NE-L, and SD. These three populations, which were closest geographically to each other, shared more plastome types and also clustered more closely in the RAPDs analysis.

The cpDNA data would describe genetic distribution as a consequence of seed dispersal, assuming chloroplasts were maternally inherited in leafy spurge. Seed dispersal could be

FIGURE 3. Dendrogram showing relationships of 112 RAPD-based genotypes from five North American leafy spurge populations. RAPDs were detected using six 9-base random primers: GGGCAATGA; CCAAGCAGT; CGGCTAGGT; GCTCACATC; TACGCACGG; ACCGCTGTG. Individuals represented the following populations: A = Colorado, Larimer Co.; B = North Dakota, Richland Co.; C = South Dakota, Minnehaha Co.; D = Nebraska, Brown Co.; $\mathrm{E}=$ Nebraska, Lancaster Co. 


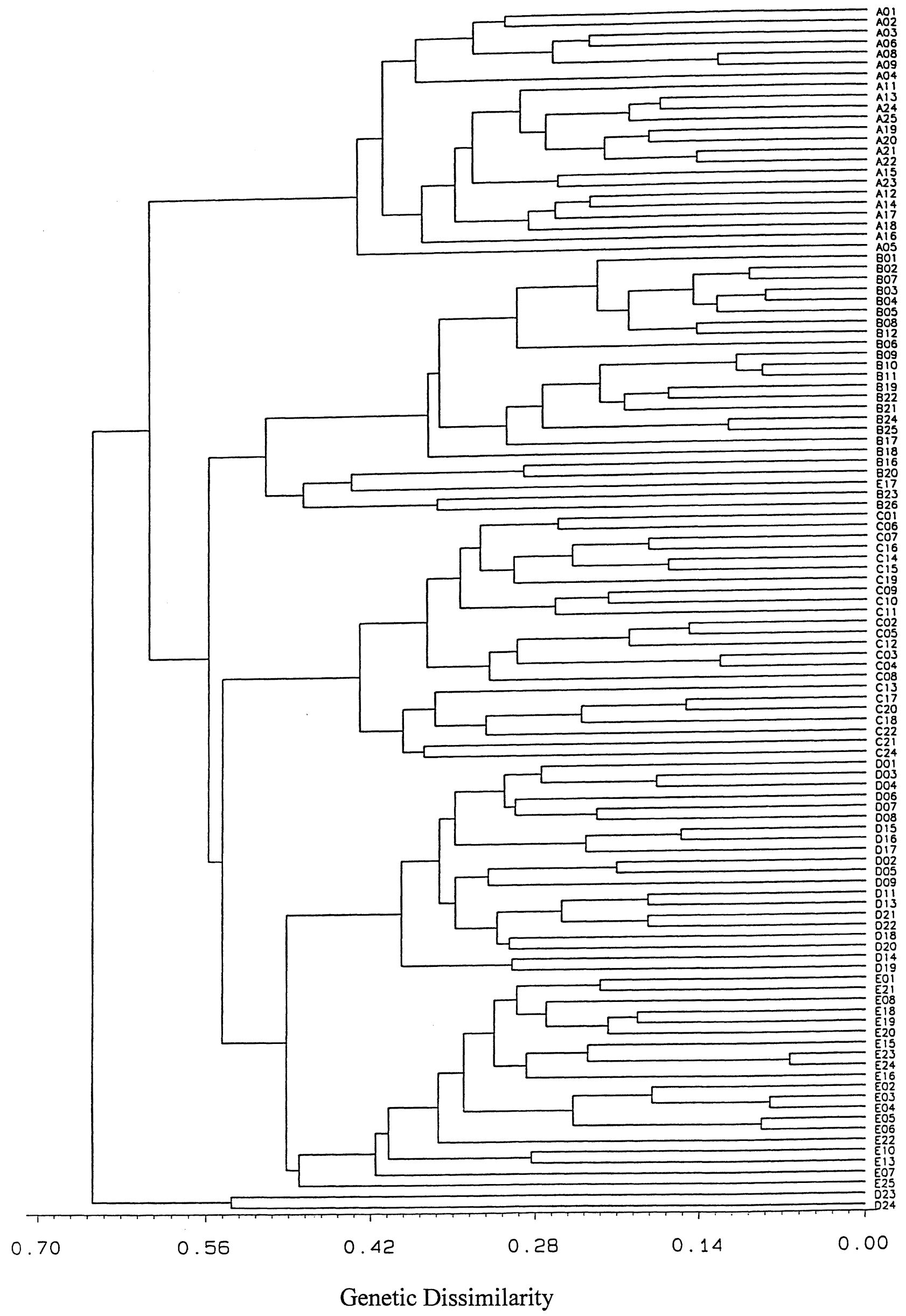

Rowe et al.: Genetic variation in N. American leafy spurge •

453 
accomplished over great distances through animals, water, or as a hay contaminant. In contrast, RAPDs would predominantly track nuclear DNA diffferences, which would reflect genetic distribution through both pollen and seed. Shorter range pollen dispersal would contribute more to relatedness within populations and among populations in closer geographic proximity. Consequently, the two marker systems will not always show the same relationships among populations and individuals. For example, the relationship of population CO to ND could be a relic of a common maternal lineage, representing independent introductions from Eurasia. Alternatively, some ancestors of individuals in the $\mathrm{CO}$ population of leafy spurge could have originated from seed introduced from North Dakota, but over time the population diverged due to mixing with individuals introduced from other locations.

An analysis of representative Eurasian populations will determine if similar variation and population structures exist in the native range of leafy spurge. It is anticipated that levels of variation will be greater in the native range, but it remains to be seen whether intrapopulation variation is as great as in North America. The current findings in North America and ongoing studies with Eurasian populations of leafy spurge will not only form a basis for identifying Eurasian origin(s) of North American leafy spurge, but will also assess genetic diversity that could have implications for the success of different biocontrol strategies.

\section{Sources of Materials}

${ }^{1}$ Foreign Disease-Weed Science Research Lab, USDA-ARS, Fort Detrick, Frederick, MD 21702.

2 DNA-specific dye Hoechst 33258, Hoefer Scientific Instruments, 654 Minnesota Street, San Francisco, CA 94107.

3 Agarose, Sigma Chemical Co., 3050 Spruce Street, St. Louis, MO 63103.

4 Synergel, Diversified Biotech, 1208 VFW Parkway, Boston, MA 03132.

${ }^{5}$ Hybond N, Amersham Corp., 2636 S. Clearbrook Drive, Arlington Heights, IL 60005.

${ }^{6}$ Stratalinker 2400, Stratagene Cloning Systems, 1101 North Torrey Pines Road, La Jolla, CA 92037.

${ }^{7}$ Magic Minipreps, Pst, Sall, Taq polymerase, restriction enzymes, Promega Corp., 2800 Woods Hollow Road, Madison, WI 53711-5399.

8 dig-dUTP, chemiluminescent substrate, alkaline phosphotase, Boehringer Mannheim Biochemicals, 9115 Hague Road, P.O. Box 50414, Indianapolis, IN 46250-0414.

${ }^{9}$ XAR5 X-ray film, Eastman Kodak Co., Rochester, NY 14650.

${ }^{10}$ Cetus DNA Thermalcycler, Perkin Elmer Corp., 761 Main Avenue, Norwalk, CT 06859.

\section{Acknowledgments}

We thank Shylaja Mysore for her excellent help in doing the preliminary RFLP survey; the USDA-ARS Office of International Research Programs and European Biological Control Laboratory, Montpellier, France; and the USDA-CSRS Rangeland Grants Program, Grant No. 91-38300-6116. Journal Series No. 11764 of the Agricultural Research Division, University of Nebraska-Lincoln, Lincoln, NE.

\section{Literature Cited}

Bartlett, B. R. and R. Van den Bosch. 1964. Foreign exploration for beneficial organisms. In P. DeBach, ed. Biological Control of Insect Pests and Weeds. London: Chapman and Hall, pp. 283-304.

Birnboim, H. C. and J. Doly. 1979. A rapid alkaline extraction procedure for screening recombinant plasmid DNA. Nucleic Acids Res. 7:15131523.

Bowditch, B. M., D. G. Albright, J.G.K. Williams, and M. J. Braun. 1993. Use of randomly amplified polymorphic DNA markers in comparative genome studies. Methods Enzymol. 224:294-309.

Brumbaugh, D. 1993. Chloroplast genome mapping in leafy spurge ( $\mathrm{Eu}$ phorbia esula L.). M.S. thesis. University of Nebraska-Lincoln, Lincoln, NE. 26 p.

Burdon, J. J. and D. R. Marshall. 1981. Biological control and the reproductive mode of weeds. J. Appl. Ecol. 18:649-658.

Dice, L. R. 1945. Measurements of the amount of ecologic association between species. Ecology 26:297-302.

Dunn, P. H. 1985. Origins of leafy spurge in North America. In A. K. Watson, ed. Leafy Spurge, Monograph No. 3. Champaign, IL: Weed Science Society of America, pp. 7-13.

Feinberg, A. P. and B. Vogelstein. 1983. A technique for radiolabelling DNA restriction endonuclease fragments with high specific activity. Anal. Biochem. 132:6-13.

Hanson, H. C. and V. E. Rudd. 1933. Leafy Spurge. Life History and Habits. Bulletin 266. Fargo, ND: North Dakota Agricultural College. $24 \mathrm{p}$.

Harris, P. 1991. Classical biocontrol of weeds: its definition, selection of effective agents, and administrative political problems. Can. Entomol. 123:827-849.

Harris, S. A. and R. Ingram. 1991. Chloroplast DNA and biosystematics: the effects of intraspecific diversity and plastid transmission. Taxon 40: $393-412$.

Louda, S. M. and R. A. Masters. 1993. Biological control of weeds in Great Plains rangelands. Great Plains Res. 3:167-199.

Messersmith, C. G., R. G. Lym, and D. S. Galitz. 1985. Biology of leafy spurge. In A. K. Watson, ed. Leafy Spurge, Monograph No. 3. Champaign, IL: Weed Science Society of America, pp. 42-56.

Milligan, B. G. 1991. Chloroplast DNA diversity within and among populations of Trifolium pratense. Curr. Genet. 19:411-416.

Neale, D. B., M. A. Saghai-Maroof, R. W. Allard, Q. Zhang, and R. A. Jorgensen. 1986. Chloroplast DNA diversity in populations of wild and cultivated barley. Genetics 120:1105-1110.

Nei, M. 1987. Molecular Evolutionary Genetics. New York: Columbia University Press. 512 p.

Nei, M. and W. H. Li. 1979. Mathematical model for studying genetic variation in terms of restriction endonucleases. Proc. Natl. Acad. Sci. 76:5269-5273.

Nissen, S. J., R. A. Masters, D. J. Lee, and M. L. Rowe. 1992. Comparison of restriction fragment polymorphisms in chloroplast DNA of five leafy spurge (Euphorbia spp.) accessions. Weed Sci. 40:63-67.

Palmer, J. D., B. Osorio, and W. F. Thompson. 1988. Evolutionary significance of inversions in legume chloroplast DNAs. Curr. Genet. 14: 65-74.

Palmer, J. D. and W. F. Thompson. 1981. Clone banks for mung bean, pea, and spinach chloroplast genomes. Gene 15:21-26.

Saghai-Maroof, M. A., K. M. Soliman, R. A. Jorgensen, and R. W. Allard. 1984. Ribosomal DNA spacer-length polymorphisms in barley: Mendelian inheritance, chromosomal location, and population dynamics. Proc. Natl. Acad. Sci. 81:8014-8018.

Soltis, D. E., P. S. Soltis, and B. G. Milligan. 1992. Intraspecific chloroplast DNA variation: systematic and phylogenetic implications. In P. S. Soltis, D. E. Soltis, and J. J. Doyle, eds. Molecular Systematics of Plants. New York: Chapman and Hall, pp. 93-116.

Stoneking, M., L. B. Jorde, B. Kuldeep, and A. C. Wilson. 1990. Geographic variation in human mitochondrial DNA from Papua New Guinea. Genetics 124:717-733.

Watson, A. K. 1985. Introduction-the leafy spurge problem. In A. K. Watson, ed. Leafy Spurge. Champaign, IL: Weed Science Society of America, pp. 1-6.

Williams, J.G.K., A. R. Kubelik, K. J. Livak, J. A. Rafalaski, and S. V. Tingey. 1990. DNA polymorphisms amplified by arbitrary primers are useful as genetic markers. Nucleic Acids Res. 18:6531-6535.

Received May 29, 1996, and approved January 28, 1997. 